\title{
Poznańscy Żydzi - szkic do dziejów: rabini, synagogi, szkoły talmudyczne, zapomniane cmentarze...
}

\author{
Na obszarze całego niemal świata znajdują się \\ w miastach i wsiach żydowskie ośrodki, w których kiedyś \\ były albo jeszcze są stare cmentarze żydowskie. \\ Unoszą się nad nimi wieki żydowskiej historii. \\ Z tych nagrobków można się uczyć historii ${ }^{1}$.
}

Streszczenie. Pierwsi żydowscy osadnicy pojawili się w Poznaniu już w początkach istnienia miasta. Pierwszy polski książę Bolesław Pobożny, idąc za przykładem cesarza Fryderyka II, który w 1283 roku nadał Żydom w Wiedniu przywileje, uczynił to samo w Poznaniu. Wraz z rozwojem miasta stopniowo zwiększała się w nim liczebność ludności żydowskiej. Na początku XV wieku co czwarty budynek przy ulicy Sukienniczej był zajmowany przez Żydów. Ulica niebawem zyskała nazwę ulicy Żydowskiej. Z przeprowadzonego w 1507 roku spisu powszechnego wynika, że Poznań był jedną z największych gmin żydowskich w Polsce.

Pierwszy cmentarz żydowski został założony w XV wieku na Złotej Górze, w pobliżu obecnego kościoła oo. Jezuitów, później przeniesiony został na teren zwany Muszą Górą, po zachodniej stronie miasta. Pod koniec XVIII wieku gmina żydowska stanowiła jedną czwartą mieszkańców. W 1793 roku Poznań przeszedł pod władanie pruskie. Podczas pożaru w 1803 roku spłonęły trzy z sześciu synagog. Działania urbanistyczne podjęte przez władze pruskie nie objęły odbudowy dzielnicy żydowskiej. Cmentarz na Muszej Górze został zlikwidowany w 1804 roku, a gmina żydowska otrzymała grunt pod nowe miejsce pochówku przy ul. Głogowskiej. Historia poznańskich Żydów jest przypowieścią o nieistniejącym miejscu, zagubionym między dziewiętnastowiecznymi kamienicami a podwórkami dzielnicy nazwanej Łazarz. 
Niegdyś znacząca społeczność żydowska w Poznaniu zniknęła. Najnowszy cmentarz został założony w latach 30 . XX wieku przy ul. Szamarzewskiego. On również już nie istnieje - obecnie znajdują się tam ogrody działkowe.

Słowa kluczowe: Żydzi, Poznań, Polacy, Niemcy, historia, synagogi, cmentarze, rabini

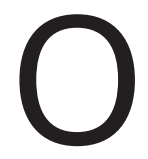

becność pierwszych osadników żydowskich Kroniki Wielkopolskie odnotowały w połowie XII wieku. W mennicach Mieszka Starego spotykamy mincerzy żydowskich, uznawanych za reprezentantów gmin żydowskich tworzących się w Kaliszu i Gnieźnie. Poza sporadyczną ochroną Żydzi, jako służebnicy książęcy, nie korzystali z ochrony prawnej. Religia, język, ubiór, pożywienie zaznaczały ich „odrębność” w stosunku do rdzennej ludności. Z upływem czasu owa odrębność nasilała się.

Pierwszym księciem polskim, idącym wzorem cesarza Fryderyka II, który w 1238 roku nadał przywilej Żydom wiedeńskim, był Bolesław Pobożny, młodszy brat Przemysła I. Przywileje nadane Żydom (tzw. statut kaliski) zostały ogłoszone w Kaliskiem i Wielkopolsce oraz na całym terenie objętym książęcą opieką w roku 1264 (Judeus nostris per totum districtum nostri dominii constitutis). Obszary te obejmowały dziedziczne księstwo kaliskie oraz księstwo poznańskie, gdzie Bolesław Pobożny sprawował władzę jako opiekun swego bratanka, małoletniego Przemysła II.

W wyniku przywileju książęcego Żydzi wielkopolscy z czasem zaczęli stanowić względnie zamożną grupę zajmującą się przeważnie transakcjami pieniężnymi, handlem wszelkimi towarami oraz rzemiosłem - głównie na potrzeby współwyznawców. O tym, że Żydzi cieszyli się specjalną ochroną ze strony księcia, zaświadczają liczne artykuły $^{2}$. Między innymi pod ochroną prawa ziemskiego znalazły się cmentarze żydowskie (art. 14), a kara za ich profanację przechodziła na rzecz księcia. Wysoka admonicja za zbezczeszczenie synagogi wynosiła dwa kamienie pieprzu i płacona była przez sprawcę wojewodom (art. 15), uprowadzenie żydowskiego dziecka karane było podobnie jak kradzież (art. 26), wszyscy sąsiedzi chrześcijańscy zobowiązani byli, pod karą pieniężną, do obrony Żyda wołającego o pomoc (art. 35). Osobny artykuł, odwołujacy się do konstytucji papieskich i autorytetu papieża, nie zezwalat poddanym księcia wielkopolskiego oskarżać Żydów o używanie krwi ludzkiej, gdyż zakazuja im tego Prawa ${ }^{3}$ - pisze poznański historyk.

Kwestii czasu powstania gminy żydowskiej w Poznaniu dotąd nie sprecyzowano, zakłada się, że została ona utworzona dopiero w połowie XIV wieku. Józef Łukaszewicz podaje dokładniejszą datę, to jest rok 1367, gdy u zbiegu ulic Szewskiej

Por. WiesioŁowski 2006, s. 7-13; Kodeks 1887, nr 605; RudZińsKA 2005, s. 345-360.

WiESIOŁOWSKI 2006, s. 10. 
i Dominikańskiej zbudowano pierwszą synagogę ${ }^{4}$ Działająca w niej szkoła talmudyczna Lamadej Poznan powszechnie uważana była za jedną z najlepszych w Europie. Z poznańskiej gminy żydowskiej wywodziły się tak znaczące postaci, jak: Gaspar da Gama (1450-1510) - podróżnik i nawigator w służbie portugalskiej w Indiach, współodkrywca Sumatry, Jawy i Moluków, uczestnik wyprawy Pedro Cabrala do brzegów Brazylii (1500) oraz rabin Juda Liw Ben Bekalela - kabalista, astronom i alchemik; to on po przeniesieniu się do Pragi miał stworzyć legendarnego Golema. W tym samym 1367 roku w dzielnicy żydowskiej wybuchł jeden z licznych pożarów nękających mieszkańców, podczas którego spłonęła także synagoga. Jacek Wiesiołowski twierdzi, że początki gminy poznańskiej były wcześniejsze niż druga połowa XIV wieku, na co wskazuje topografia Poznania:

\begin{abstract}
W regularnym planie idealnego miasta, z ulicami wytyczonymi przez mierniczych i przecinającymi się pod kątem prostym w układzie szachownicowym, zakłócenia występują tylko w dwóch miejscach: na skarpie doliny Warty widoczna jest biegnąca ukośnie ul. Kozia, wiodąca niegdyś do kościoła św. Marcina, i na terenach dawnej osady św. Gotarda, koło kościoła Dominikanów, w rejonie dawnej ul. Żydowskiej. Wydaje się możliwe, że tereny tej osady nie uległy regulacji (dokonanej dopiero w początkach XIX wieku) i jako mniej wartościowe zostały zasiedlone po lokacji przez ludność żydowskąa
\end{abstract}

Obszary zamieszkałe przez poznańskich Żydów charakteryzowała nieregularna zabudowa, którą cechowało występowanie (podobnie jak w Kaliszu i Gnieźnie) dodatkowych uliczek i zaułków nieuzasadnionych regularnym planem miasta, będących pozostałością dawnej osady. Poznańska gmina była, obok gmin krakowskiej, lubelskiej i lwowskiej, jedną z najstarszych i przez niemal 700 lat jedną z najważniejszych na ziemiach polskich. Jej rozkwit wiąże się z napływem uciekinierów z Niemiec, Francji i Czech, który nastąpił w wyniku gwałtownych prześladowań spowodowanych oskarżeniem o wywołanie zarazy morowej ${ }^{6}$. Najstarsze dokumenty gminy nie zachowały się do naszych czasów, niewiele więc wiadomo o pierwszych rabinach poznańskich. Pierwszym znanym z nazwiska był rabin Pechno, który przewodził gminie w latach 1389-13937. Nie wiadomo, kto był jego następcą i kto stał na czele gminy, gdy w 1399 roku oskarżenia o profanację hostii, które dały początek legendzie o Trzech Hostiach i zbudowaniu kościoła Bożego Ciała w Poznaniu przy ul. Żydowskiej, stały się przyczyną gwałtowanych prześladowań ze strony mieszczan.

\footnotetext{
ŁukASZEWiCZ 1832, s. 65-66.

WiesioŁOWSKi 2006, s. 12-13.

Por. STĘSZEWSKA-LESZCZYŃSKA 1992, s. 102-103.

Por. JACOBSEN 1927, www.archive.org/stream/jewishencycloped10sing/jewishencycloped10sing _djvu.txt [dostęp: 24.05.2020]
} 
Podobne oskarżenia w historii poznańskiej gminy miały miejsce wielokrotnie. Tylko w XV wieku pogromy o różnym podłożu pojawiały się w latach 1434, 1447 i $1464^{8}$.

Leżącemu na skrzyżowaniu ważnych szlaków Poznaniowi kolejne lata przyniosły intensywny rozwój, a wraz z rozwojem miasta wzrastała liczba ludności żydowskiej. Ze spisu ludności przeprowadzonego w 1507 roku wynika, że Poznań w owym czasie był jednym z największych skupisk Żydów w Polsce. W 1510 roku w mieście nad Wartą osiedlili się Żydzi wypędzeni z Brandenburgii, nieco później z południa Europy przybyli arabsko-hiszpańscy Sefardyjczycy. Kilka lat później Żydom poznańskim przyznano uprawnienia handlowe, w 1521 roku zwolnieni zostali zaś z opłat celnych na całym terytorium Rzeczypospolitej. Pierwszy odnotowany $\mathrm{w}$ dokumentach miasta cmentarz żydowski został założony w XV wieku w miejscu zwanym Złotą Górą, w pobliżu obecnego kościoła ojców Jezuitów. Później został on przeniesiony na Muszą Górę.

Główne skupisko żydowskich mieszkańców Poznania wyznaczała ulica Żydowska - dawniej nosząca nazwę Sukienniczej, biegnąca na przedłużeniu północnej pierzei Starego Rynku ku zakolu rzeki Warty. W 1536 roku w dzielnicy żydowskiej wybuchł wielki pożar, który strawił ją niemal w całości: spłonęła synagoga, ratusz, szkoła, trzy szpitale i dwadzieścia trzy domy. Po pożarze władze zażądały wyganiania Żydów z miasta bądź przeniesienia do podmiejskiej dzielnicy Rybaki (Rybitwy) ${ }^{9}$. Żądania włodarzy Poznania nie zostały spełnione, ograniczono natomiast liczbę ludności żydowskiej przez zredukowanie liczby domów, jakie mogli zasiedlać. W XVI wieku w Poznaniu mieszkało ponad 3000, czyli ok. 10\% wszystkich mieszkańców miasta, osób pochodzenia żydowskiego, i był to w owym czasie - powtórzmy - najliczniejszy w kraju i jeden z największych w Europie ośrodków zamieszkanych przez Żydów. W Poznaniu wówczas rozkwitała kultura i nauki talmudyczne, istotnym centrum studiów była miejscowa jesziwa.

W czerwcu 1590 roku wybuchł kolejny pożar, który strawił całą dzielnicę żydowską wraz z synagogą oraz przylegającą dużą część miasta zamieszkałą przez chrześcijan. Za kolejne pożary (1613) pustoszące miasto i dzielnicę żydowską, gdzie budowano głównie z drewna, obwiniano Żydów. Wyganiano ich zatem na przedmieścia; tu na skutek katastrofalnych warunków sanitarnych szerzyły się epidemie dziesiątkujące ludzi.

\footnotetext{
8 Muszyński/Bergman 2006, s. 16-17; NoŻyński 1931, s. 86-99, 249-263.

9 Rybaki (Rybitwy) po raz pierwszy pojawiają się w zapisach w $1441 \mathrm{r}$. Była to osada służebna zamieszkała przez rybaków, poławiających ryby w przepływającej tutaj Strudze Karmelickiej, dziś nieistniejącej. Prawdopodobnie osada istniała od XIII wieku, była wówczas wyspą, być może ukształtowaną sztucznie. Trójkątne centrum osady, której zrąb powstał prawdopodobnie w okresie kształtowania się państwa piastowskiego, czytelne jest do dziś na skrzyżowaniu ulic Rybaki i Strzałowej. Por. Topolski 1988.
} 
Zmienne losy Polski i Poznania w XVII i XVIII wieku pozostawiły głębokie, dramatyczne ślady na społeczności żydowskiej. W czasie wojen szwedzkich (16551660) gminę poznańską najpierw nękał głód, potem epidemie. Podczas nieudanego oblężenia Poznania przez wojska polskie w 1656 roku z 2000 rodzin zamkniętych $\mathrm{w}$ mieście przetrwało zaledwie $300^{10}$. Gdy żydzi wraz z protestantami zostali przez chrześcijan oskarżeni o kolaborację ze Szwedami, resztka gminy padła ofiarą pogromów, tak ze strony mieszczan, jak i wojska.

$$
* * *
$$

4 lipca 1793 roku sekretarz konfederacji targowickiej Jakub Biliński, wykonując polecenie władz pruskich i zamykając działalność sądu grodzkiego w Poznaniu, jako ostatni zapis umieścił, wielokrotnie w tamtym czasie przypominane słowa: Regni Poloniae finis ${ }^{11}$. Ten dzień oznaczał koniec działalności władz polskich w Poznaniu w czasach porozbiorowych. Nastąpił okres tzw. pierwszej okupacji pruskiej i czasy Księstwa Warszawskiego. Pod koniec XVIII wieku społeczność żydowska stanowiła niemal jedną czwartą mieszkańców Poznania. W 1794 roku, według spisu powszechnego, na 12538 mieszkańców stolicy Wielkopolski było: 7437 katolików, 3021 osób wyznania mojżeszowego, 1918 luteran, 115 kalwinów, 47 wyznawców Kościoła greckokatolickiego ${ }^{12}$.

Po wyniszczającym pożarze w roku 1803, który strawił północno-wschodnią część Starego Miasta i dzielnicę żydowską, pozbawiając ponad 5000 osób dachu nad głową, z sześciu istniejących wówczas w Poznaniu synagog spłonęły trzy. Zniszczeniu uległa stara synagoga, która - konsekwentnie odbudowywana po kolejnych pożarach - przetrwała niemal 500 lat. Wkrótce wypalone fragmenty miasta zdecydowano się odbudować i zmodernizować ${ }^{13}$, niwelując m.in. ciasne, pełne zaułków getto, w miejsce którego wytyczona została jedna szeroka ulica Żydowska, która istnieje do dziś. Likwidując getto, pozwolono Żydom osiedlać się i nabywać nieruchomości we wszystkich dzielnicach miasta, bez żadnych ograniczeń.

10 Por. Guldon/WijaczKa 1995.

1 Por. ŁukASZEWICZ 1832, s. 65.

12 Por. Dzieje Wielkopolski 1969, s. 880.

13 Powołano Komisję Retablissement, która w ciągu sześciu lat miała przeprowadzić odbudowę i rozbudowę Poznania. Przeznaczono na ten cel 770000 talarów. Kierowanie całością prac powierzono Komisji, w skład której wchodziło czterech urzędników kamery i magistratu oraz architekt. Pracami kierował Ferdinand Triest. Por. JEDLIŃsKa 2007, s. 91-98. Szczegółowe opracowania dotyczące Komisji Retablissement por. PARAdOwSKA 2016, s. 341-363; ŻUCHOWsKi 2016, s. $282-308$. 
Podjęta w tamtym czasie - już przez władze pruskie i przez władze pruskie finansowana - zakrojona na wielką skalę akcja urbanistyczna ${ }^{14} \mathrm{w}$ Poznaniu objęła także odbudowę dzielnicy żydowskiej. Jak pisze Ostrowska-Kębłowska, uzdrowienie wypalonych fragmentów starego miasta obejmowało przede wszystkim „likwidację ciasnego, pełnego wąskich zaułków getta, w miejscu którego wytyczono jedną, szeroką ulicę Żydowską"15.

\section{$* * *$}

Najstarszy cmentarz żydowski w Poznaniu, zlokalizowany początkowo na Złotej Górze, przeniesiony został na teren położony po zachodniej stronie miasta, na niewielkie wzniesienie, obecnie zniwelowane, nazywane Muszą Górą (Muszyńska Góra, Muszinska Góra). Znajdował się on między obecnym placem Wolności a ulicą 3 Maja, sięgając do pierzei dzisiejszego placu Cyryla Ratajskiego. Po zajęciu Poznania przez Prusaków, którzy zamierzali wprowadzić w mieście własne plany modernizacyjne, Żydzi zostali zmuszeni do opuszczenia starego cmentarza na Muszej Górze. Już od 1793 roku nowe władze planowały na tych terenach zbudowanie Nowego Miasta ${ }^{16}$; projekty te przyspieszył pożar z 1803 roku, który zniszczył trzy synagogi. Architekt Carl Schildener (1767-1843) zaproponował wówczas wybudowanie nowej synagogi w „stylu starohebrajskim”17.

Prusacy odkupili dzierżawione od wieków przez Żydów tereny od szlachcica Dobrzyckiego i ostatecznie cmentarz zlikwidowano w $1804 \mathrm{roku}^{18}$. Gminie żydowskiej przekazano natomiast grunt pod nowe miejsce pochówków przy odległej od Starego Miasta ulicy Głogowskiej. Podczas przenosin z cmentarza na Muszej Górze na nową działkę zaginęły liczne zabytkowe macewy. Obecnie nie ma żadnych śladów istnienia średniowiecznej nekropolii. Na jej miejscu wzniesiono na początku XX wieku (rok ukończenia 1910) okazałą, neobarokową, pięciokondygnacyjną kamienicę Towarzystwa Ubezpieczeniowego Union (plac Wolności 14).

Majer Samuel Bałaban w wydanej w 1929 roku książce Zabytki historyczne Żydów w Polsce o nekropolii położonej w okolicach obecnego placu Wolności w Poznaniu pisał:

\footnotetext{
14 Od połowy XVIII w. w Europie dążono do „otwarcia” starych miast przez wyburzanie obwarowań, niwelację fos, bram miejskich tak, by mieszkańcy mogli mieć dostęp do otwartych zielonych przestrzeni. Władze pruskie, idąc za przykładem włodarzy Monachium, Bremy, Hamburga, Lubeki czy Wrocławia, zdecydowały, by także Poznań został objęty tą reformą. Por. OstrowskA-KęBŁOWSKA 1992, s. 114-115; ŻUCHOWSKi 2016, s. 282-308.

15 OstrowsKa-KęBŁOWSKA 1992, s. 115.

16 OstrowSKA-KęBŁOWSKA 1982, s. 115; ŻUCHOWSKi 2016, s. 285 i n.

17 OstrowsKa-KęBŁOWSKa 1982, s. 144; Bergman 2004, s. 38.

18 TrZeCIAKOWSCY 1982, s. 18.
} 
Gorzej niż z krakowskim rzecz się ma z cmentarzem poznańskim. Wedle planów i wskazówek w archiwum, znajdował się on na dzisiejszym placu Wolności, w samem centrum nowego miasta, a opodal starego. Czy to był najstarszy z cmentarzy żydowskich jest nam niewiadome, żaden z lokalnych historyków Poznania nie wynotował tego faktu. Tyle jest wiadome, że w roku 1805 zniesiono ten cmentarz, przyczem kości kilku męczenników z r. 1736, a z niemi i niektóre nagrobki przeniesiono na nowy cmentarz. Lud opowiada, że królowa pruska Luiza mieszkała koło cmentarza i nie chcąc mieć przed oczyma pogrzebów i nagrobków żydowskich, kazała znieść cmentarz. Klęska pod Jeną miała być „karą dla Prusaków za to świętokradztwo". W każdym razie przepadły wszystkie prastare, a nawet i mniej stare nagrobki (za wyjątkiem kilku), ta strona archeologji żydowskiej w Poznaniu jest dla nauki stracona ${ }^{19}$.

Dziewiętnastowieczny Poznań, rozdarty konfliktami narodowościowymi, społecznymi, politycznymi - przez Polaków postrzegany jako jedna z trzech stolic rozbitego państwa, przez napływających do Poznania Niemców oraz przez sąd pruski jako prowincjonalny ośrodek administracyjno-wojskowy - sukcesywnie przekształcany $\mathrm{w}$ miasto-twierdzę, miasto-więzienie, miasto-koszary, zdawał się skupiać dramat miejsca uobecniającego i wcielającego w życie idee pruskiej władzy i przemocy nad państwem polskim. Niemieccy mieszkańcy Poznania cenili architektoniczne walory budowli fortecznych powstających $\mathrm{w}$ mieście, Polacy tymczasem odczuwali niepewność i zagrożenie wywołane faktem znalezienia się wewnątrz narażonej na oblężenie twierdzy; znamionowało ich poczucie bezradności w obliczu braku perspektyw na zmianę sytuacji. To poczucie beznadziejności, presji psychicznej wynikało z uciążliwej dominacji fortu nad miastem, które zostało całkowicie jemu podporządkowane.

W latach 1833-1848 zmieniło się położenie niezwykle zróżnicowanej społeczności żydowskiej w Poznaniu. Obok ludzi bardzo biednych, którzy przybyli do miasta głównie ze wschodnich ziem dawnej Rzeczypospolitej, mieszkali Żydzi od dawna związani z Wielkopolską, mający kontakty z Berlinem, Hamburgiem, Lipskiem, Wrocławiem, Pragą - zasymilowani, zamożni, wykształceni. Żydzi zamieszkali w Poznaniu w latach 1835-1880 na tle ustawicznie powiększającej się liczby Niemców oraz w stosunku do narodowości polskiej stanowili znaczną grupę charakteryzującą się dużą dynamiką rozwoju, majętną i studiującą na europejskich uniwersytetach. Najznamienitsze nazwiska ludzi wybitnie wykształconych, zainteresowanych sprawami społecznymi, kulturalnymi w Wielkopolsce to: Bernard i Samuel Jaffé, Eduard Kaatz, Moritz Mamroth, rodziana Santerów. Żywa działalność licznej żydowskiej inteligencji była tym bardziej znacząca, że nie wytworzyło jej w Poznaniu mieszczaństwo niemieckie.

19 Bąaban 1929, Zabytki historyczne Żydów w Polsce, za: www.kirkuty.xip.pl/poznan.htm; www.jhi.pl/psj/Balaban_Majer_(Meir)_Samuel [dostęp: 1.11.2016]. 
Wielką postacią tradycyjnego judaizmu w Europie i dziewiętnastowiecznym Poznaniu był Rabi Akiba Eger (1761-1837) - autorytet w dziedzinie prawa religijnego Żydów, autor m.in. komentarzy do Talmudu, społecznik zaangażowany w opiekę nad ofiarami cholery w 1831 roku. Zasłynął jako przeciwnik reformowanego judaizmu. Był rabinem w poznańskiej gminie od 1814 roku; po jego śmierci rabinat objął jego syn Salomon Eger, także wybitny znawca Talmudu, który postulował przyjmowanie przez Żydów poznańskich kultury niemieckiej. Wspierał również projekty żydowskiego osadnictwa rolniczego w Wielkopolsce.

W 1833 roku Eduard von Flotwell, nadprezydent prowincji, zamierzając związać najzamożniejszych przedstawicieli społeczności żydowskiej z Niemcami i uczynić ogniwem swej antypolskiej polityki, przygotował ustawę, podług której uboga ludność podlegała nadal licznym ograniczeniom; tymczasem najbogatsi - ludzie nauki oraz „osoby szczególnie zasłużone dla Prus” - mogli ubiegać się o tzw. naturalizację. Wymagała ona m.in. posługiwania się w życiu publicznym i zawodowym tylko językiem niemieckim, który stał się językiem wykładowym w szkołach żydowskich. Naturalizacja wprawdzie zrównywała podstawy prawne życia prywatnego i działalności ekonomicznej, nie dawała jednak praw miejskich i obywatelskich, które dopiero po 1843 roku przyznano 58 naturalizowanym Żydom. Po roku 1850 ci obywatele, którzy legitymowali się wysokim cenzusem majątkowym, zajmowali trzecią część miejsc w Radzie. Narodowe antagonizmy, stymulowane przez przedstawicieli administracji pruskiej, nierozumiejącej bliskich - często od pokoleń - związków Polaków z Niemcami, ze szczególną ostrością ujawniły się w końcowym okresie wypadków Wiosny Ludów. Przybysze z Prus, jakkolwiek często dobrzy organizatorzy, inicjatorzy ciekawych projektów kulturalnych, nie odgrywali w Wielkopolsce roli przywódców. Jeżeli ich stosunek do miejscowych Niemców był lekceważacy - pisze Zofia Ostrowska-Kębłowska - to do Żydów odnosili się pogardliwie, natomiast Polaków traktowali otwarcie jako element niebezpieczny $i$ wrogi $i^{20}$. Przypomnijmy, że w Księstwie wydarzenia Wiosny Ludów były mniej ruchem społecznym, bardziej zaś narodowym. Żydom rok 1848 przyniósł, zgodnie z ustawami wydawanymi przez władze w Berlinie, dalsze wyzwolenie społeczne i okazję zbliżenia się do Niemców. Jednocześnie zaostrzyły się różnice między Polakami i Niemcami, niezależnie od przynależności społecznej.

Okresem, który przyniósł rzeczywiste prawa polityczne zamożnej warstwie społeczności żydowskiej, był rok 1848. Opowiedzenie się po stronie Niemców Komitetu, w skład którego wchodziło kilkunastu mieszczan pochodzenia żydowskiego - pisze Ostrowska-Kębłowska - rzutować zaczęło na stosunek Polaków do Żydów, których

20 OstrowsKa-KęBŁOWsKa 1982, s. 145, za: Jaffé 1909, s. 300-301. Praca Moritza Jaffé, pochodzącego ze starej poznańskiej rodziny żydowskiej, pisana głównie na podstawie źródeł, stanowi obecnie nieoceniony dokument obrazujący życie dziewiętnastowiecznego Poznania. Wyd. polskie: JAFFÉ 2012, s. 197 i n. 


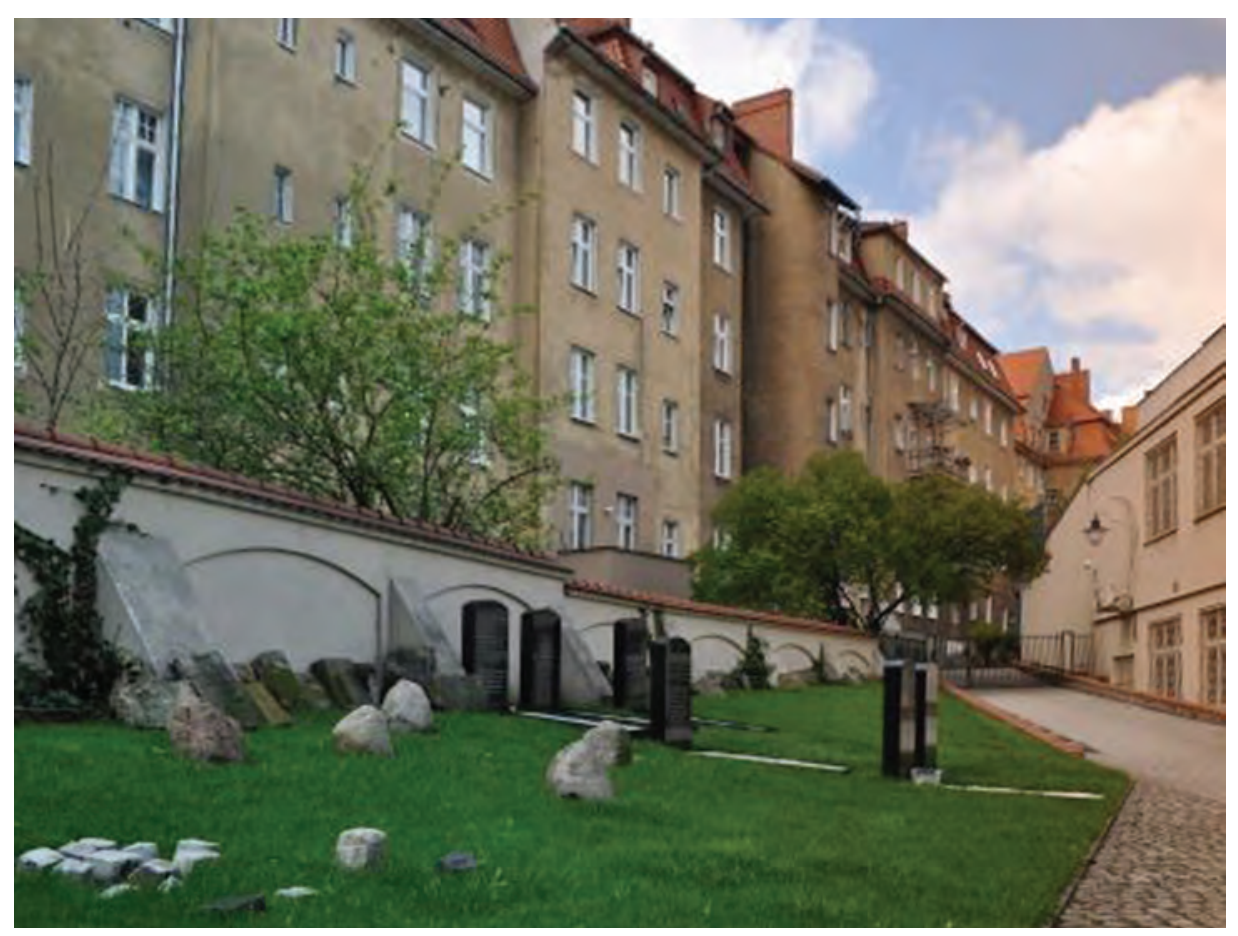

1. Cmentarz żydowski w Poznaniu przy ul. Głogowskiej 26a. Stan obecny, www.eksploratorzy.com.pl/ viewtopic.php?t=6709 [dostęp: 27.09 .2019 ]

bojkotowano później na równi z Niemcami ${ }^{21}$. Wzrastające konflikty na tle narodowościowym zaczęły utrudniać Żydom budowanie niezależności ekonomicznej, którą Polacy i Niemcy skłonni byli traktować jako teren walk polityczno-narodowych. Takie postępowanie - z punktu widzenia mieszczaństwa żydowskiego - było irracjonalne i sprzeczne z zasadami gospodarczego liberalizmu.

Po odzyskaniu przez Polskę niepodległości większość ludności żydowskiej wyjechała do Niemiec i Austrii. Odpływ był tak znaczny, że w latach 1919-1939 Żydzi stanowili zaledwie 1\% mieszkańców stolicy Wielkopolski. Liczba Żydów w Poznaniu sukcesywnie malała. Z 6000 Żydów, mieszkających tu w 1860 roku pod koniec lat 30. XX wieku pozostało ok. 1500.

Owa masowa emigracja z restytuowanej po latach zaborów Polski tłumaczyłaby zapomnienie czy wręcz wymazanie ze świadomości istnienia żydowskiej nekropolii usytuowanej na Łazarzu przy ulicy Głogowskiej. Kiedy po 1889 roku zelżały ograniczenia forteczne, rozpoczęła się intensywna urbanizacja Łazarza. W ciągu kilku lat wytyczono główne ulice zabudowywane stopniowo wielopiętrowymi kamienicami, powstała nowa elektrownia i nowoczesne zakłady wodociągowe, uruchomiono regularne połączenie ze Śródmieściem, najpierw omnibusami, następnie

21 OstrowsKa-KęBŁOWSKA 1982, s. 221. 
tramwajem. W latach 1900-1918 dzielnica rozbudowywała się w tempie błyskawicznym, a powstałe w tamtym czasie budowle ukształtowały jej architektoniczny charakter. Rozbudowujący się po I wojnie światowej Poznań „wchłoną” niejako cmentarz, zapomniany i w pewnym sensie opuszczony przez żydowskich mieszkańców. Kolejnym czynnikiem prowokującym rozbudowę Łazarza była Powszechna Wystawa Krajowa w 1929 roku, z okazji której na terenie dzielnicy powstało szereg nowych ulic i budynków.

Podczas II wojny światowej Łazarz został kilkakrotnie zbombardowany. Ulica Głogowska, przy której założono nowy cmentarz żydowski, jest najważniejszą arterią komunikacyjną i mieszkalną Łazarza, rozpoczyna się za skrzyżowaniem z mostem Dworcowym i biegnie przez Górczyn ku południowym rogatkom Poznania. Podczas II wojny światowej nekropolia została zdewastowana przez hitlerowców. Macewy wykorzystano między innymi do utwardzania dróg i chodników oraz do prac budowalnych na terenie willowej dzielnicy Sołacz, gdzie mieszkali niemieccy oficerowie. Dzieła zniszczenia dokończono po wyzwoleniu w 1945 roku, wznosząc w tym miejscu pawilony targowe. Rozbudowa po II wojnie światowej terenów Międzynarodowych Targów Poznańskich zdecydowała o zmianie strukturalnej niegdyś peryferyjnej dzielnicy, a wszelkie ślady grobów cmentarza żydowskiego zostały zatarte. Cmentarz był dość rozległy, sądząc z zachowanych sprzed wojny zdjęć lotniczych przedstawiających dzielnicę oraz uwzględniając odległość dzielącą tereny Międzynarodowych Targów Poznańskich od zachowanego fragmentu cmentarza przy ulicy Głogowskiej 26a, gdzie obecnie na podwórku kamienicy znajduje się kilka zachowanych grobów ${ }^{22}$. Na cmentarzu przy ulicy Głogowskiej 26a pochowany został Akiba Eger - rabin Poznania i Wielkiego Księstwa Poznańskiego, jak wspomniano wyżej, wybitny uczony i talmudysta, autor licznych dzieł z zakresu prawa religijnego, rektor poznańskiej jesziwy. Na steli nagrobnej Akiby wyryty był napis: Tu spoczywa rabin, nasz rabin Akiba Eiger. Odszedt do sług bożych w świętej gminie Maerkisch Friedland i świętej gminie Poznań został zabrany do swego ludu. W czwartek 13 dnia tiszri roku 5598 według krótkiego rachunku $u^{23}$. Obecnie, tak jak to miało miejsce przed I wojną światową, grób poznańskiego rabina stał się celem pielgrzymek wyznawców judaizmu. W 1911 roku w „Residenzstadt Posen und Ihre Verwaltung” pisano: skromny nagrobek $w$ miejscu spoczynku rabina Akiby Egera jest szczególnie często odwiedzany przez będących w Poznaniu rosyjskich Żydów. W czasie II wojny światowej miejsce pochówku Akiby Egera, razem z całym cmentarzem, zrównano z ziemią. Na dawnym grobie rabina przez lata stał garaż. W czasie renowacji cmentarza w 2007 roku dla rabina Egera i jego rodziny zostały postawione nowe macewy, wykonanie z czarnego kamienia, z napisami w języku hebrajskim.

22 www.eksploratorzy.com.pl/viewtopic.php?f=7\&t=6709.

23 Tłum. inskrypcji z nagrobka WiTKOWSKi 2006, s. 49. 
$129 \mid \begin{gathered}\text { TECHNE } \\ \text { TEX N H } \\ \text { SERIA NOWA }\end{gathered}$

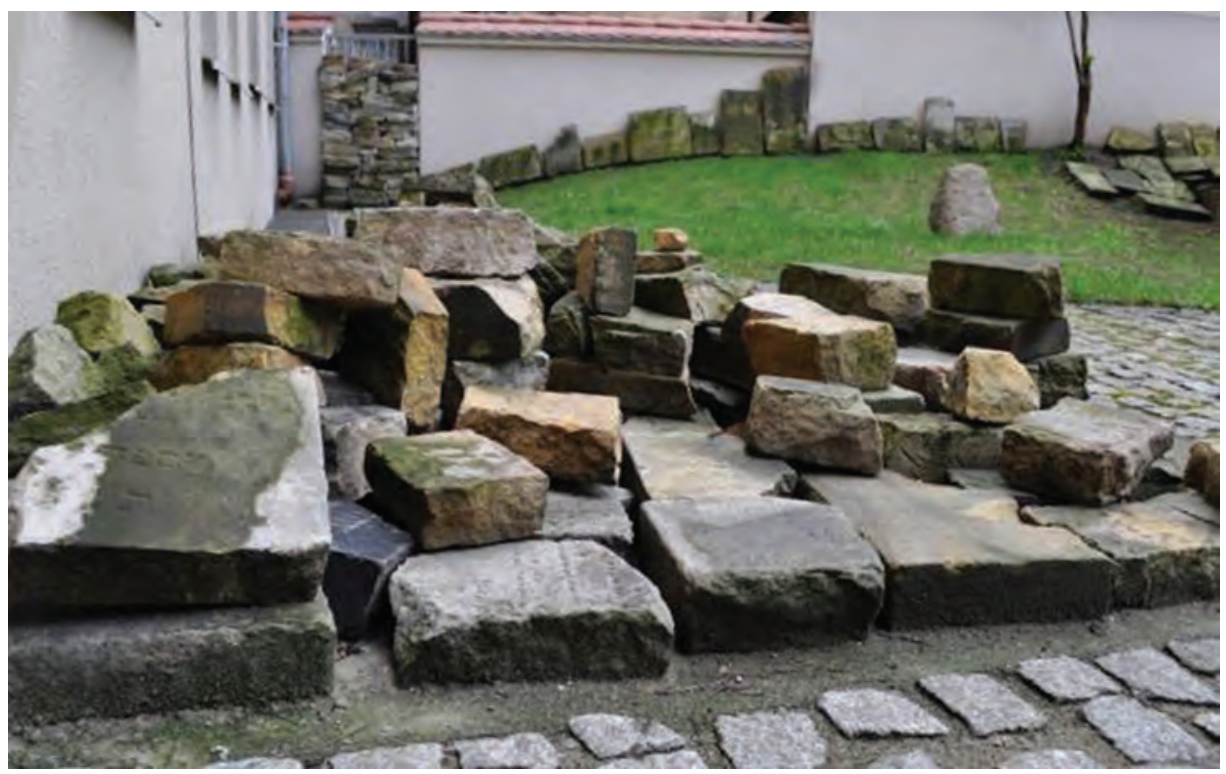

2. Cmentarz żydowski w Poznaniu przy ul. Głogowskiej 26a. Stan obecny, www.eksploratorzy.com.pl/ viewtopic.php?t=6709 [dostęp: 27.09 .2019 ]

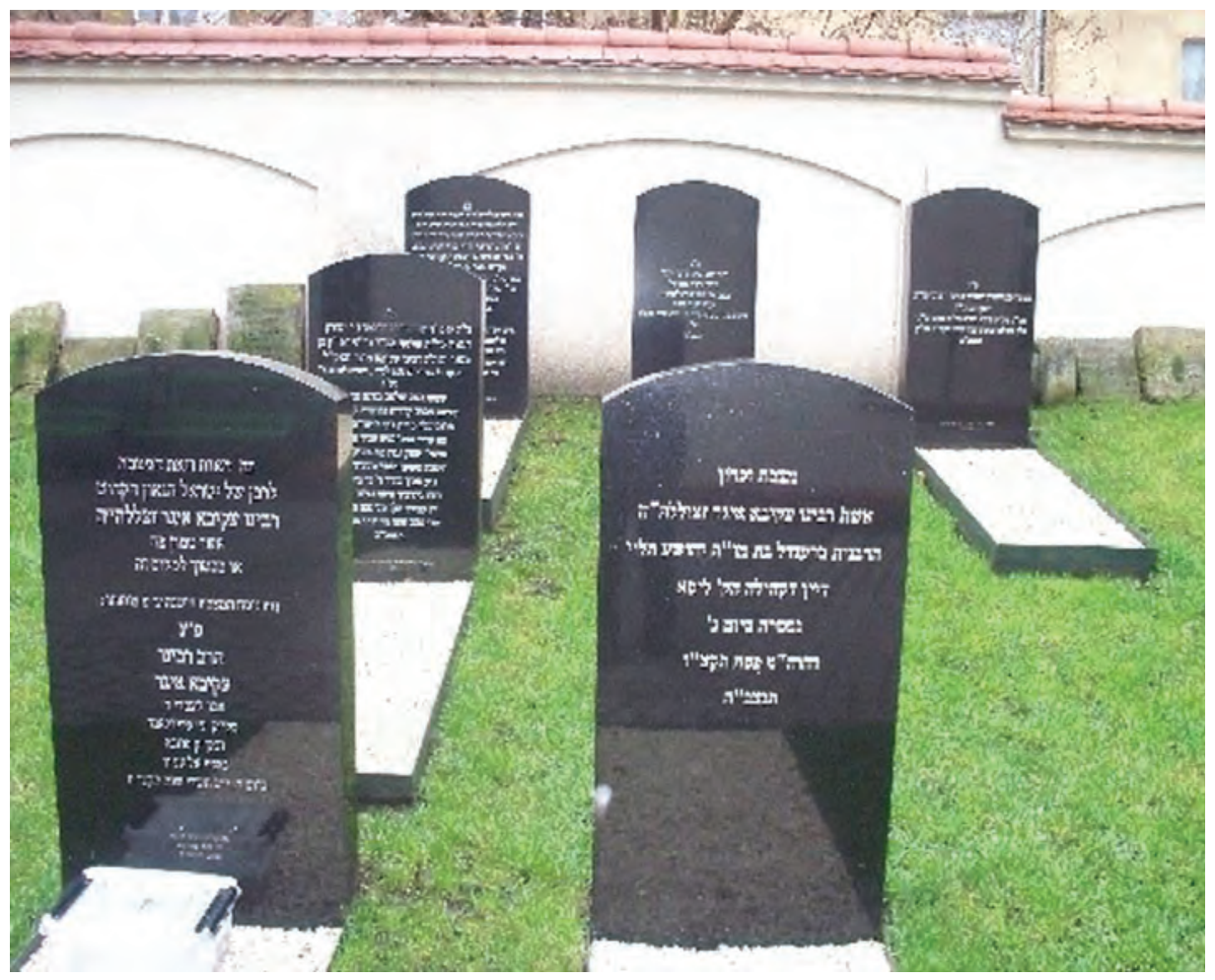

3. Cmentarz żydowski w Poznaniu przy ul. Głogowskiej 26a. Stan obecny, www.eksploratorzy.com.pl/ viewtopic.php?t=6709 [dostęp: 27.09.2019] 


\section{TECHNE \\ T E X N H \\ SERIA NOWA

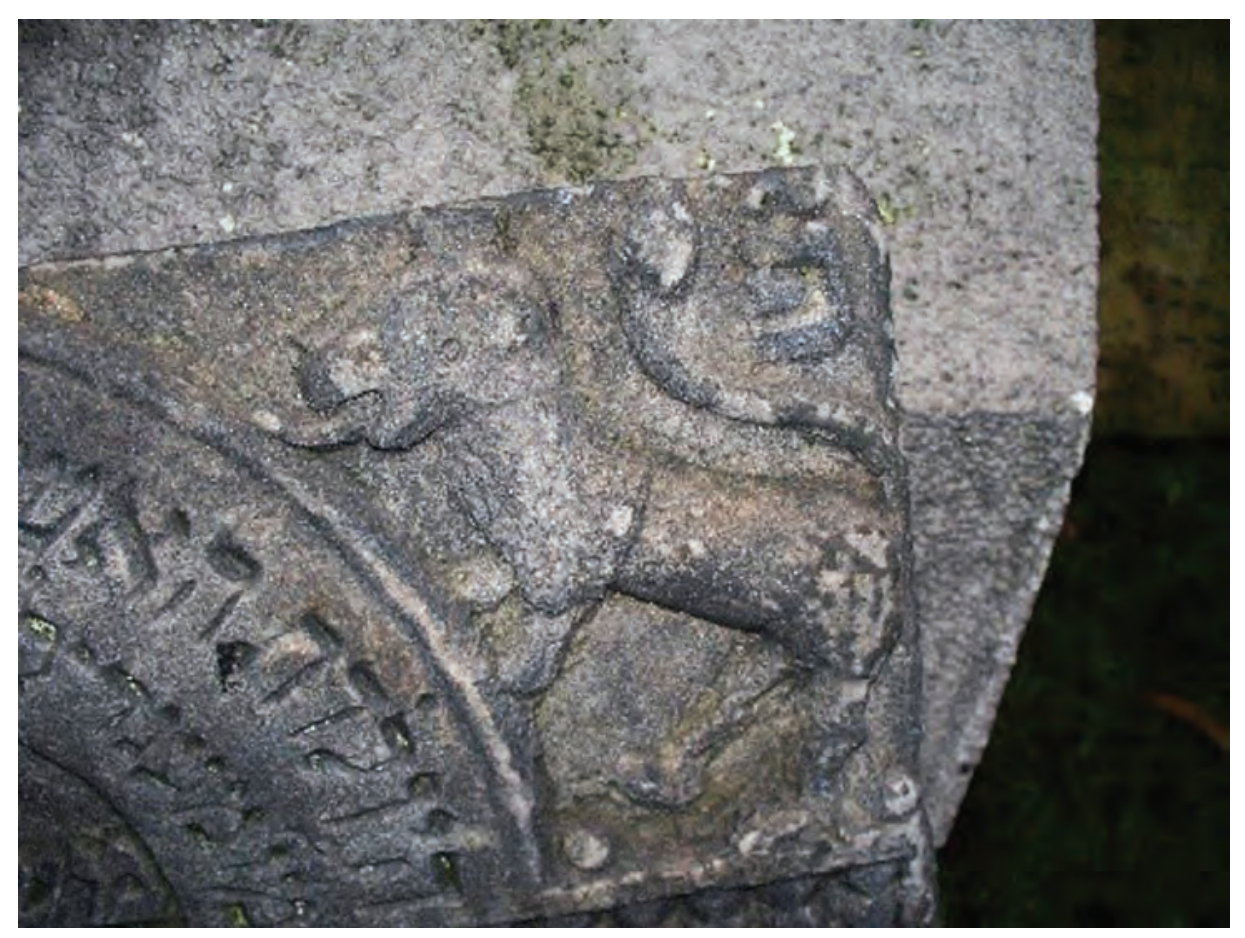

4. Lapidarium ze starych nagrobków. Poznań, ul. Głogowska 26a, www.eksploratorzy.com.pl/ viewtopic.php?t=6709 [dostęp: 27.09.2019]

Przez wiele lat środowiska żydowskie, z Komitetem Ochrony Cmentarzy Żydowskich w Europie na czele, podejmowały starania na rzecz budowy lapidarium na terenie dawnego cmentarza żydowskiego w Poznaniu. Długotrwałe negocjacje ze Spółdzielnią Mieszkaniową „Grunwald” oraz właścicielami stojących tu zabudowań dobiegły końca w grudniu 2006 roku. Uzgodniono, że na podwórzu przy ul. Głogowskiej 26a zostaną ustawione stylizowane na macewy kamienne tablice, w tym nagrobek Akiby Egera. Jesienią 2007 roku podczas prac odkopano kilka starych kamieni nagrobnych. 30 kwietnia 2008 roku na odzyskanym skrawku cmentarza postawiono macewy i utworzono lapidarium. Przybyły z Izraela rabin Menashe Ekstein wyznaczył miejsca pochówków, w tym, co najważniejsze - grób Akiby Egera. Rabin Schlesinger strzegł, aby nie zostały złamane prawa dotyczące pochówków. Rabinowi asystowali bracia Yoshua i Samuel Halpern - potomkowie Akiby Egera - fundatorzy przedsięwzięcia. Obecni byli również rabini z Zurichu i Londynu. Nad całością czuwała przewodnicząca Poznańskiej Filii ZGWŻ Alicja Kobus oraz przewodniczący Gminy w Gdańsku Michał Samet. Współtwórcami dzieła byli: Rabinacka Rada Europy Ochrony nad Cmentarzami Żydowskimi, ZGWŻ w Poznaniu - z przewodniczącą Alicją Kobus, Międzynarodowe Targi Poznańskie oraz Spółdzielnia Mieszkaniowa „Grunwald Osiedle Łazarz”. Autorem projektu 


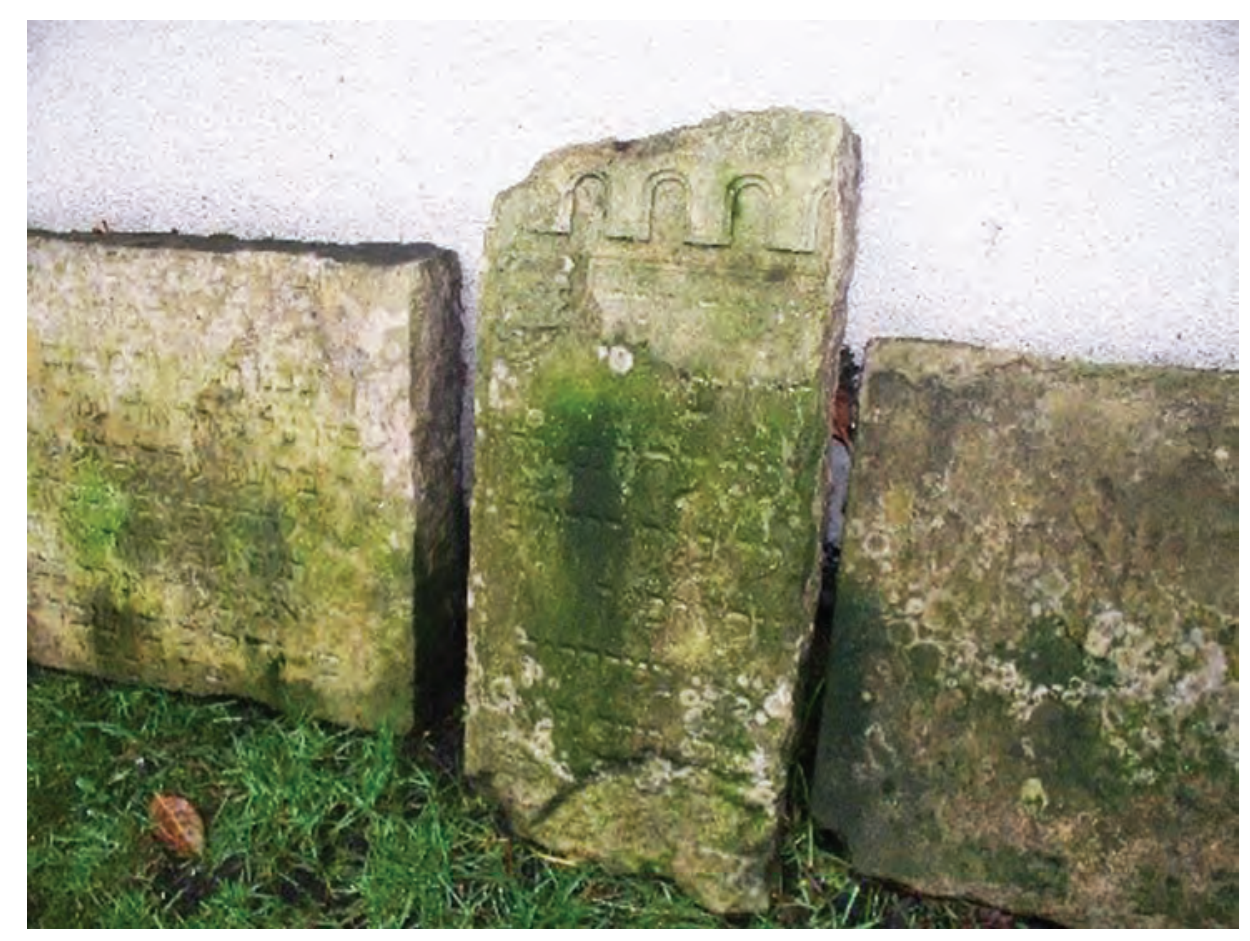

5. Lapidarium ze starych nagrobków. Poznań, ul. Głogowska 26a, www.eksploratorzy.com.pl/ viewtopic.php?t=6709 [dostęp: 27.09.2019]

cmentarza jest architekt Jacek Wilczak, nadzór budowlany prowadził inż. Włodzimierz Całka, a wykonawcą robót budowlanych był zespół Andrzeja Grochalskiego.

W 1958 roku na cmentarzu komunalnym w dzielnicy Miłostowo utworzono wydzieloną kwaterę żydowską. W jej obrębie znajduje się kilkanaście powojennych grobów oraz dziesiątki macew ze zniszczonego cmentarza żydowskiego przy ul. Głogowskiej. Jest to niezwykły zbiór starych nagrobków, o dość dobrze widocznych hebrajskich inskrypcjach, macewy wykonane są z prostych, często nieociosanych kamieni granitowych, pozbawionych (czy raczej zatartych) symbolicznych płaskorzeźb. Centralną część kwatery zajmuje kilka masowych mogił, w których spoczywają ofiary Holocaustu. Tu również złożono kości wykopane podczas budowy Targów Poznańskich.

Historia żydowskiego cmentarza w Poznaniu to przypowieść o nieistniejącym miejscu, zagubionym między kamienicami i podwórkami Łazarza. Niegdyś znacząca intelektualnie i liczebnie społeczność żydowska zniknęła. Bogata kultura poznańskiej gminy została unicestwiona. Nieliczne macewy odnajdywane w różnych punktach miasta, niektóre, jak można zobaczyć na prezentowanych fotografiach, pochodzą zapewne z XVIII i XIX wieku. Na ścianie przy bramie od strony ulicy Głogowskiej umieszczone zostały marmurowe tablice, $\mathrm{z}$ informacją o historii nekropolii. 
Jeszcze jeden cmentarz żydowski w Poznaniu przywołała w swych wspomnieniach Anna Olejniczak, która w liście przysłanym do redakcji „Gazety Wyborczej” w 2002 roku pisze:

\begin{abstract}
Ostatni cmentarz żydowski w Poznaniu założono w latach trzydziestych XX wieku przy ul. Szamarzewskiego 12. Na jego temat jest najmniej informacji i najmniej dowodów jego istnienia. [...] W księdze adresowej Poznania z 1933 roku nieruchomość ta figuruje jako działka Karola Schötza z Włoskowic, pow. pińczowski, ziemia kielecka, ale w dokumentach Zarządu Miejskiego w Poznaniu pt. Spis cmentarzy ewangelickich i żydowskich przejętych przez gminę z $1945 \mathrm{roku}^{24}$ teren ten nosi nazwę: Cmentarz Żydowski. Działka została przejęta przez Wydział Zieleni Miejskiej i zapisana w księdze wieczystej jako nieruchomość przy ul. Engerströma. W tej chwili na terenie tego cmentarza znajdują się ogródki działkowe.
\end{abstract}

Poszukując śladów cmentarzy żydowskich w Poznaniu, warto odwiedzić Muzeum Martyrologiczne w Żabikowie koło Poznania. Tutaj podczas II wojny światowej działał Reichsautobahnlager - obóz pracy, w którym żydowscy więźniowie zmuszani byli do budowy autostrady prowadzącej z Poznania do Frankfurtu. W pracach wykorzystywano m.in. macewy. Na terenie Muzeum przechowywanych jest wiele fragmentów płyt nagrobnych, pozostałych po tej budowie. Nie wiadomo, które pochodzą z poznańskich cmentarzy, a które z cmentarzy w okolicznych miejscowościach. Część macew poddano restauracji, próbując odtworzyć ich polichromie. $\mathrm{Na}$ pobliskiej posesji złożono również kilka metalowych przęseł ogrodzenia cmentarza żydowskiego z ulicy Głogowskiej.

Niedawno znaleziono w Poznaniu macewy, którymi wyłożona była ulica Wenecjańska i ulica Czartoria na Chwaliszewie. Ulica Czartoria, dawniej ruchliwa, po niesławnej „regulacji” koryta Warty w latach 60 . XX wieku, urywa się tuż nad brzegiem rzeki. Płyty, odnalezione w 2005 roku przez przygodnych spacerowiczów, zostały wydobyte $\mathrm{z}$ bruku i umieszczone w lapidarium ${ }^{25}$.

$$
* * *
$$

Pozostałość cmentarza żydowskiego w Poznaniu to estetyczny artefakt, którego wartość symboliczna nie może zastąpić wartości mistycznej. Bejt kwarot (hebr. „dom grobów") to poświęcony teren, na wieczność przypisany zajmującym go umarłym. Wedle tradycyjnych wierzeń żydowskich nad cmentarzem unoszą się duchy umarłych, których oddano ziemi, duchy znające już ludzki los w niebiosach. Ziemia,

24 Por. APP, nr zespołu 1226, sygnatura 62.

25 KAFKA/CYRUK/BIELAWSKI; www.cmentarze-zydowskie.pl/poznan.htm [dostęp: 25.05.2020]. 
$133 \mid \begin{gathered}\text { TECHNE } \\ \text { TEX N H } \\ \text { SERIA NOWA }\end{gathered}$

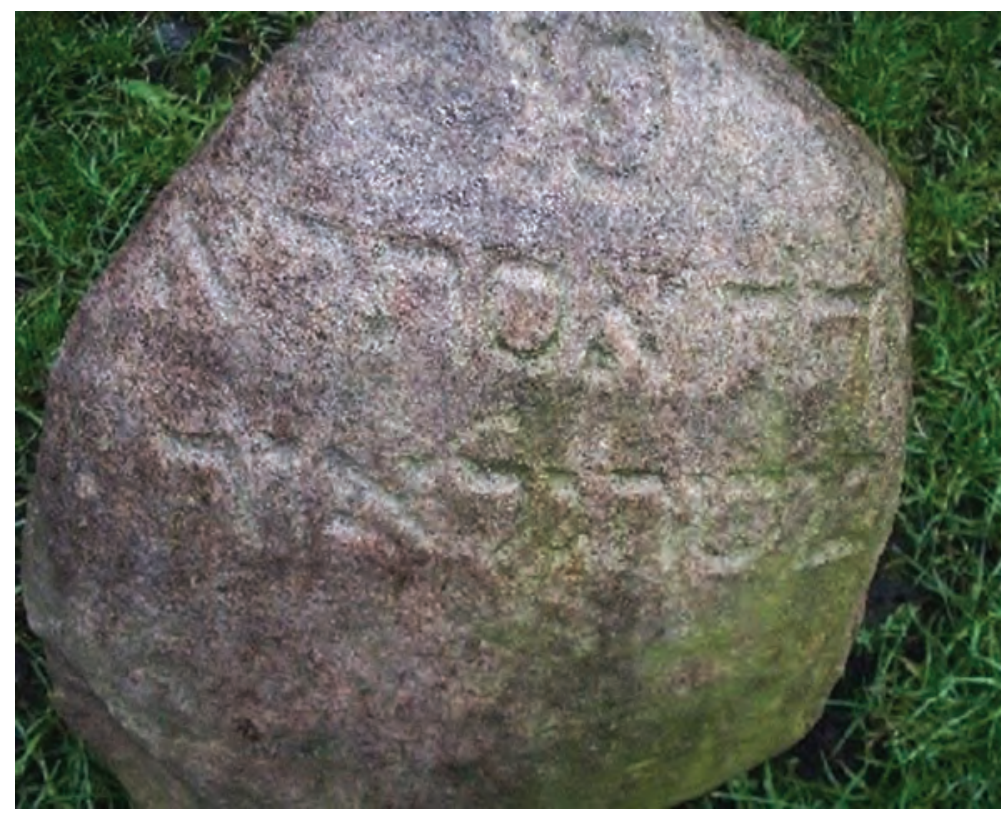

6. Najstarsze nagrobki złożone na cmentarzu przy ul. Głogowskiej 26a w Poznaniu, www.eksploratorzy. com.pl/viewtopic.php?t=6709 [dostęp: 27.09.2019]

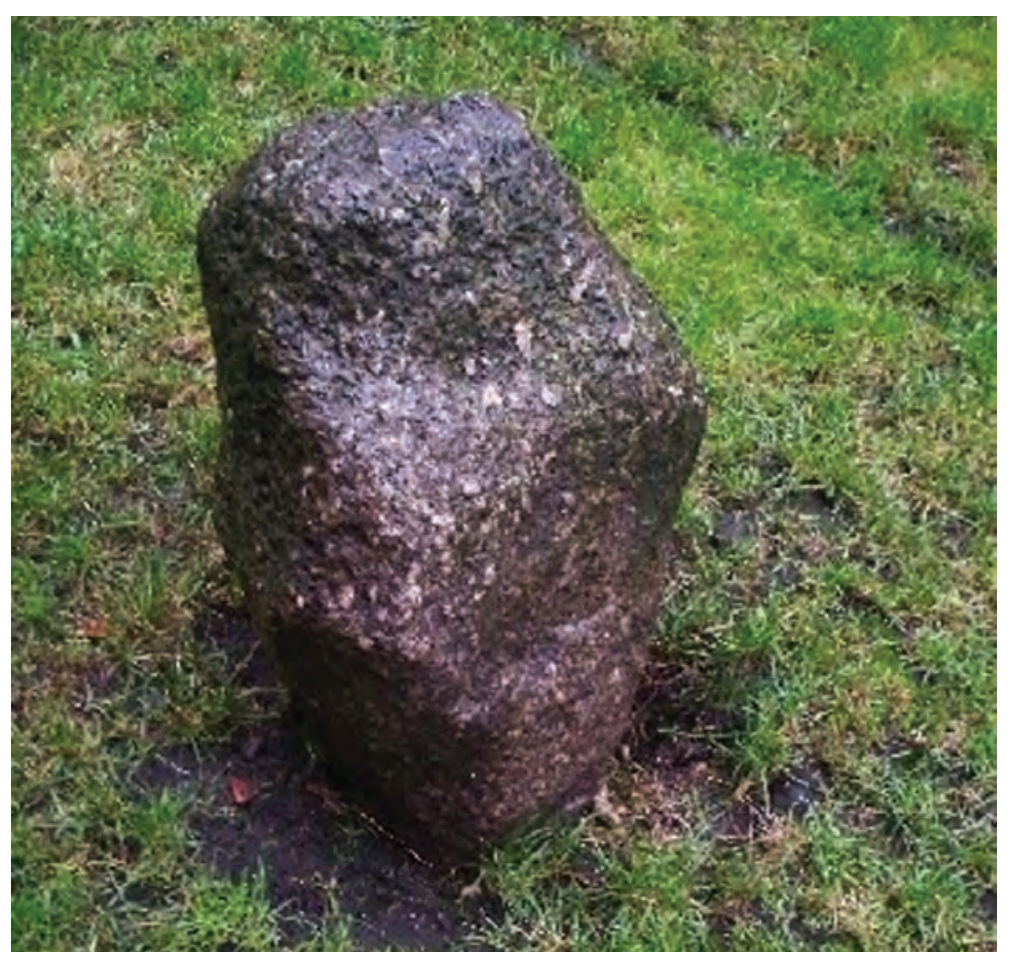

7. Najstarsze nagrobki złożone na cmentarzu przy ul. Głogowskiej 26a w Poznaniu, www.eksploratorzy. com.pl/viewtopic.php?t=6709 [dostęp: 27.09.2019] 
$w$ której pochowany został zmarly, należy do niego. Na zawsze. W tym miejscu nie może już spoczać żaden człowiek. Wszystko, co w tym miejscu wyrośnie należy do grobu ${ }^{26}$. Duchy umarłych krążące nad pełną wielkomiejskiego zgiełku ulicą Głogowską w Poznaniu prowadzą żywych ku bramie kamienicy, której podwórze zachowało szczątki i pamięć o dawnej świetności tutejszej gminy żydowskiej. Tak więc trwaja żydowskie cmentarze niewzruszone i oczekuja kresu dni (Księga Dn 12, 13 - wers ostatni).

\section{Bibliografia}

\section{Źródła i opracowania}

APP - Archiwum Państwowe w Poznaniu, nr zespołu 1226, sygnatura 62.

Dzieje Wielkopolski 1969 - Dzieje Wielkopolski, t. 1, Do roku 1793, red. Jerzy Topolski, Poznań 1969.

Guldon/WiJACZKa 1995 - Zenon Guldon, Jacek Wijaczka, Ludność żydowska w Wielkopolsce w drugiej połowie XVII wieku, [w:] Żydzi w Wielkopolsce na przestrzeni dziejów, red. Jerzy Topolski, Krzysztof Modelski, Poznań 1995, s. 26-31.

JAfFé 1909 - Moritz Jaffé, Die Stadt Posen unterpreussischer Herrechaft, Duncker und Humbolt, Leipzig 1909.

JAfFÉ 2012 - Moritz Jaffé, Poznań pod panowaniem pruskim, przekł. Joanna Baron-Grzesiak, red. Przemysław Matusik, Poznań 2012.

JEDLIŃSKa 2007 - Eleonora Jedlińska, Rafał Jakubowicz - synagoga/plywalnia, „Pro Memoria” 2007, s. 91-98.

Kodeks 1887 - Kodeks dyplomatyczny Wielkopolski, t. I, Poznań 1887, nr 605.

Łukaszewicz 1832 - Józef Łukaszewicz, Obraz historyczno-statystyczny miasta Poznania w dawniejszych czasach, t. 1-2, Poznań 1832.

MuszyŃski/Bergman 2006 - Lech Muszyński, Bronek Bergman, Sylwetki poznańskich rabinów, „Kronika Miasta Poznania. Poznańscy Żydzi”, Wydawnictwo Miejskie, Poznań 2006, t. 3, s. 14-37.

NożyŃski 1931 - Tadeusz Nożyński, Żydzi poznańscy w XV wieku 1379-1502, „Kronika Miasta Poznania" 1931, s. 86-263.

Ostrowska-K巨̨BŁowsKa 1982 - Zofia Ostrowska-Kębłowska, Architektura i budownictwo w Poznaniu w latach 1790-1880, Warszawa-Poznań 1982.

Paradowska 2016 - Aleksandra Paradowska, Archiwalia dotyczące działalności Komisji Odbudowy (Retablissementskommision) w malych miasteczkach Wielkopolski / Die Archichivalien $z u$ den Retablissementsakkivitäten in großpolnischen Kleinstädten, [w:] Retablissement: PreuBische Stadtbaukunst in Polen und Deutschland | Urbanistyka pruska w Polsce i w Niemczech, (red. Andre Bischoff, Joanna Drejer, Ulrich Reinisch, Christof Baier, Tadeusz J. Żuchowski, Berlin 2016, s. 341-362.

RudzińsKa 2005 - Jolanta Rudzińska, Żydzi w średniowiecznym Poznaniu, [w:] Civitas Posnaniensis, red. Zofia Hilczer-Kurnatowska, Tomasz Jurek, Poznań 2005, s. 345-360.

26 VRies 2006, s. 400. 
STęSZEWSKA-LeszCZYŃSKa 1992 - Ewa Stęszewska-Leszczyńska, Poznańskie synagogi, „Kronika Miasta Poznania”, 1992, nr 1-2, s. 102-118.

Topolski 1988 - Jerzy Topolski, Dzieje Poznania, t. 1, Warszawa-Poznań 1988, s. 171.

Trzeciakowscy 1982 - Maria i Lech Trzeciakowscy, W dziewiętnastowiecznym Poznaniu: życie codzienne miasta 1815-1914, Poznań 1982.

VRIEs 2006 - Simon Philip de Vries Mzn., Obrzędy i symbole Żydów, przekł. i oprac. Andrzej Borowski, Kraków 2006.

WIESOŁOWSKi 2006 - Jacek Wiesiołowski, Bolesław i Jolenta, czyli początki polskiej tolerancji, „Kronika Miasta Poznania. Poznańscy Żydzi”, t. 3, Poznań 2006, s. 7-13.

Witkowski 2006 - Rafał Witkowski, Rabin Akiva Eger, „Kronika Miasta Poznania. Poznańscy Żydzi”, t. 3, Poznań 2006, s. 44-50.

ŻUCHOwsKi 2016 - Tadeusz J. Żuchowski, Wpływ pruskiej urbanistyki na rozwój urbanistyczny Poznania / Der Einfluss der prußischen Stadtbaukunst auf die stadtebanliche Entwicklung Poznans, [w:] Retablissement: Preußische Stadtbaukunst in Polen und Deutschland / Urbanistyka pruska $w$ Polsce i $w$ Niemczech, red. Andre Bischoff, Joanna Drejer, Ulrich Reinisch, Christof Baier, Tadeusz J. Żuchowski, Berlin 2016, s. 282-308.

\section{Netografia}

BAŁABAn 1929 - Majer Samuel Bałaban, Zabytki historyczne Żydów w Polsce, http://www.kirkuty. xip.pl/poznan.htm [dostęp: 1.11.2016].

JaCOBSOn 1927 - Jacob Jacobson, Posen, [w:] Judisches Lexikon, Berlin 1927, http://www.archive. org/stream/jewishencycloped10sing/jewishencycloped10sing_djvu.txt [dostęp: 25.05.2020].

KAFKa/Cyruk/BielawsKi - Grażyna Estera Kafka, Artur Cyruk, Krzysztof Bielawski, Cmentarze żydowskie, http://www.eksploratorzy.com.pl/viewtopic.php?f=7\&t=6709 [dostęp: 1.11.2016]

Strecke 2016 (rec.) - Reinhart Strecke, Christof Baier, André Bischoff, Joanna Drejer, Ulrich Reinisch, Tadeusz J. Żuchowski (Hrsg.), Retablissement. Preußische Stadtbaukunst in Polen und Deutschland / Urbanistyka pruska w Polsce i w Niemczech, Berlin 2016. ArtHist.net, Jul 6, 2017, https://arthist.net/reviews/15917 [dostęp: 2.09.2020].

http://cmentarze-zydowskie.pl/poznan.htm [dostęp: 25.05.2020].

http://www.jhi.pl/psj/Balaban_Majer_(Meir)_Samuel [dostęp: 1.11.2016].

http://www.kirkuty.xip.pl/poznan.htm [dostęp: 1.11.2016].

http://www.kunstgeschichte.hu-berlin.de/2011/08/preussische-stadtbaukunst-in-polen-und -deutschland/ [dostęp: 2.09.2020].

https://www.baufachinformation.de/leseprobe.jsp?isbn=9783867322492 [dostęp: 2.09.2020]. 


\section{The short history of Jews in Poznań: rabbis, synagogues, Talmudic schools, and forgotten cemeteries...}

$\mathrm{T}$ he presence of the Jews in Poznań dates back to the early years of the city. The first Polish prince Bolesław the Pious, following the example of Emperor Frederic II who in 1283 granted privileges to the Jews in Vienna, has done the same in Poznań. As Poznan grew, the population of Jews in the city has been gradually growing. In 1507, based on the census conducted in that year, it appears that Poznan, at the time, was one of the largest Jewish communities in Poland.

The first Jewish cemetery recorded in the town's documents was established in the $15^{\text {th }}$ century in a place called Złota Góra (Goldenberg), then it was moved to the western side to a hill called Musza Góra. At the end of the $18^{\text {th }}$ century, the Jewish community made up almost a quarter of the inhabitants of Poznań. In 1793 the city came under the Prussian rule. During the fire in 1803 which devastated the northeastern part of the Old Town and the Jewish quarter. An urban planning-action undertaken by the Prussian authorities didn't include reconstruction of the Jewish quarter. The Jewish cemetery on Musza Góra existed until 1804 when the Jews were forced to leave. The Jewish community was given land for a new cemetery on Głogowska Street.

The history of Poznańs Jews is a parable of a non-existent place, lost between the tenement houses and the backyard of Lazarus district (Lazarz). Once intellectually and the quantitatively significant Jewish community has disappeared. The latest Jewish cemetery in Poznan has been established in the 1930s on Szamarzewskiego Street. In the documents of the Municipal Executive Board in Poznań, it is called: Jewish Cemetery. Nowadays it's nonexistent, as it was turned into gardens.

Keywords: Jews, Poznań, Poles, Germans, history, synagogues, cemeteries, rabbis 